\title{
Multi-level Governance of Banking Regulation in the European Union: Evidence from Developing Bank Supervision in Bulgaria and Hungary
}

Citation for published version (APA):

Spendzharova, A. (2010). Multi-level Governance of Banking Regulation in the European Union: Evidence from Developing Bank Supervision in Bulgaria and Hungary. Journal of European Integration, 32(3), 249268. https://doi.org/10.1080/07036331003646850

Document status and date:

Published: 01/01/2010

DOI:

10.1080/07036331003646850

Document Version:

Publisher's PDF, also known as Version of record

Document license:

Taverne

Please check the document version of this publication:

- A submitted manuscript is the version of the article upon submission and before peer-review. There can be important differences between the submitted version and the official published version of record.

People interested in the research are advised to contact the author for the final version of the publication, or visit the DOI to the publisher's website.

- The final author version and the galley proof are versions of the publication after peer review.

- The final published version features the final layout of the paper including the volume, issue and page numbers.

Link to publication

\footnotetext{
General rights rights.

- You may freely distribute the URL identifying the publication in the public portal. please follow below link for the End User Agreement:

www.umlib.nl/taverne-license

Take down policy

If you believe that this document breaches copyright please contact us at:

repository@maastrichtuniversity.nl

providing details and we will investigate your claim.
}

Copyright and moral rights for the publications made accessible in the public portal are retained by the authors and/or other copyright owners and it is a condition of accessing publications that users recognise and abide by the legal requirements associated with these

- Users may download and print one copy of any publication from the public portal for the purpose of private study or research.

- You may not further distribute the material or use it for any profit-making activity or commercial gain

If the publication is distributed under the terms of Article $25 \mathrm{fa}$ of the Dutch Copyright Act, indicated by the "Taverne" license above, 


\section{Multi-level Governance of Banking Regulation in the EU: Evidence from Developing Bank Supervision in Bulgaria and Hungary}

\section{Aneta B. Spendzharova}

To cite this article: Aneta B. Spendzharova (2010) Multi-level Governance of Banking Regulation in the EU: Evidence from Developing Bank Supervision in Bulgaria and Hungary, European Integration, 32:3, 249-268, DOI: 10.1080/07036331003646850

To link to this article: https://doi.org/10.1080/07036331003646850

曲 Published online: 28 May 2010.

Submit your article to this journal

Џll Article views: 328

Q View related articles $\sqsubset$

4 Citing articles: 1 View citing articles 준 


\title{
Multi-level Governance of Banking Regulation in the EU: Evidence from Developing Bank Supervision in Bulgaria and Hungary
}

\author{
ANETA B. SPENDZHAROVA \\ Department of Political Science, Maastricht University, The Netherlands
}

\begin{abstract}
Recent bank collapses as a result of the global financial crisis have highlighted the need to keep international bank supervision practices up to date with technological and product innovations in the sector. In the 1980s, coordination in international financial regulation resulted from multilateral negotiations in which states played a central role. Since then, international banking regulation has undergone significant transformation. This article probes the explanatory power of multi-level governance in the case of European bank regulation. According to the first proposition examined here, experts play an essential role in policy formulation. The second proposition stipulates that public, private and international actors participate in decision-making and shape the regulatory outcomes together with national regulators. The third proposition states that independent regulatory agencies, rather than government ministries, implement regulations and monitor compliance. The analysis is based on evidence from two new EU member states, Bulgaria and Hungary, that are representative of the two most common types of bank supervision organizational structure in the EU.
\end{abstract}

KEY WORDS: Bank supervision, regulatory politics, multi-level governance, international finance, experts, independent regulatory agencies

Following World War II, the international financial architecture was characterized by 'embedded liberalism'. Governments endorsed free trade internationally but maintained capital controls to ensure domestic policy autonomy

Correspondence Address: Aneta B. Spendzharova, Department of Political Science, Maastricht University, PO Box 616, Grote Gracht 90-92, 6200 MD Maastricht, The Netherlands. E-mail: a.spendzharova@maastrichtuniversity.nl 
(Ruggie 1982; Helleiner 1994, 48-50). However, since the 1970s, the growing internationalization of the world's largest economies has generated considerable pressures to liberalize capital flows. Especially after the end of the Cold War, governments have increasingly dismantled capital controls (Helleiner 1994, 146-68). As a consequence of the increased cross-border capital flows, international banks have faced larger negative externalities of risky lending. The bankruptcy of Herstatt Bank in West Germany and Franklin National Bank in the USA in 1974 provided an impetus for rethinking banking sector regulatory practices on the international level (Lütz 2000, 2; Bank for International Settlements 2007). More recently, the failure of Barings (UK) in 1995 after speculation with futures contracts and the collapse of mortgage lenders Northern Rock (UK) and IndyMac (USA) as well as US investment banks Bear Stearns and Lehman Brothers in 2008 as a result of the subprime mortgage crisis have highlighted the need to keep international bank supervision practices up to date with technological and product innovations in the sector.

In the 1980s, coordination in international banking regulation was considered a successful case of regime development (Krasner 1983; Kapstein 1989, 1994). The impetus for harmonizing regulatory standards came from states, in particular the USA and the UK, using the Basel Committee on Banking Supervision as a venue for multilateral negotiations (Kapstein 1989, 339; Genschel and Plümper 1997, 630; Lütz 2000). During that period, banks tried to influence the regulatory framework by lobbying institutions in their respective countries such as the Federal Reserve System, the Bank of England, or the Bundesbank (Genschel and Plümper 1997; Lütz 2000).

What important changes have occurred in international banking since then? First, capital markets now account for a larger share of financial intermediation than bank lending (Barth et al. 2006). Second, large institutional investors such as pension funds and mutual funds have become important market players (Lütz 2000,4). Third, there has been a significant growth in foreign exchange trading and new financial products such as derivatives and credit default swaps (Barth et al. 2006). As a result, a more flexible framework of international banking regulation has emerged since the 1990s. Because the number of risk-takers on international capital markets, especially those channelling private capital flows, has increased significantly, the new regulatory framework requires extensive coordination between the domestic and international level as well as public and private actors (Lütz 2000, 4-5).

A systematic examination of the emerging decision-making pattern in international banking regulation reveals important challenges to the traditional hierarchical framework of the Westphalian state (Caporaso 1996; Keohane and Nye 2000). Recent analyses have described global financial governance $^{1}$ as a patchwork of overlapping jurisdictions and hierarchies (Ruggie 1993; Cerny 2005) and have emphasized the growing policy relevance of professional societies, advocacy groups, and corporations alongside governments (Rosenau 1997). 


\section{Theoretical Framework: Multi-level Governance}

The multi-level governance (MLG) framework has been used widely in political science and public policy to account for the changing role of the state and the rise of non-state actors in decision-making. This article uses the insights of MLG to examine the emerging governance structures in European banking regulation. I draw on Liesbet Hooghe and Gary Marks' $(2001,2)$ definition of multi-level governance as a system in which 'authority and policy-making influence are shared across multiple levels of government subnational, national, and supranational'. In addition, as Simona Piattoni $(2009,167)$ has pointed out, the large number of salient policy actors is a distinctive feature of the MLG framework, where 'actors link different government levels and populate the policy networks'.

Multi-level governance analyses have focused primarily on the structural, cohesion, and regional development policies of the European Union (Hooghe and Marks 2004), but recently the theoretical insights of this framework have also been applied to economic governance (Knodt 2004; Perraton and Wells 2004). The European multi-level system is comprised of supranational institutions, member state governments, subnational, and private actors. While the regional and local levels have been prominent in analyzing the EU's structural and regional policies, in the case of banking sector regulation, private actors such as business organizations and international networks of policy experts are more relevant.

From a methodological standpoint, I use the flexibility of MLG to reconcile rationalist and constructivist explanations of policy change. ${ }^{2}$ This article relies on the rationalist approach to study the pattern of actor mobilization and coalition formation in banking sector regulation. The multi-level governance framework provides us with tools to examine the changing constellations of actors on different levels of policy-making. At the same time, the article also incorporates constructivist insights about the importance of ideas, knowledge, and policy learning. I investigate the accumulation and transmission of knowledge across international networks of policy experts.

Liesbet Hooghe and Gary Marks (2003) have drawn an important distinction between two types of multi-level governance. Type I MLG comprises general-purpose jurisdictions that bundle together multiple functions and a range of policy responsibilities. In this setting, describing the majority of EU policies, citizens are located in a set of nested jurisdictions where only one relevant jurisdiction applies at any particular territorial scale (Hooghe and Marks 2003, 236). By contrast, Type II MLG is composed of specialized jurisdictions and is fragmented into functionally-specific components such as monitoring water quality or adjudicating trade disputes. Type II multi-level governance jurisdictions tend to be lean and flexible, their number is potentially large, and the scales on which they operate vary significantly (Hooghe and Marks 2003, 236). Thus Type II MLG is more relevant for policies in the international domain.

In my view, Type II multi-level governance describes more accurately current developments in banking sector regulation. According to Hooghe 
and Marks (2003, 240), Type II jurisdictions are best suited to solve particular problems such as 'managing a common pool resource and setting a technical standard'. Both characteristics apply to banking sector regulation: adopting prudential standards can be regarded as a collective good; agreement on shared technical standards is essential for cross-border regulatory coordination. A distinctive characteristic of Type II multi-level governance, as analyzed by Hooghe and Marks (2003, 238), is that policy-making is less hierarchical and rigidly structured. The policy outcome is shaped by a 'wide range of public and private actors who collaborate and compete in shifting coalitions' (Hooghe and Marks 2003, 238).

A widely-used classification of the policy-making cycle singles out the following stages: agenda-setting, policy formulation, decision-making, implementation, and evaluation (Howlett et al. 2009). An examination of the banking regulation policy cycle in its entirety is beyond the scope of this article. In order to identify and examine systematically important governance shifts in European banking regulation, I focus on the three central stages shaping the final outcome - policy formulation, decision-making, and implementation.

The following three sections present and elaborate on three propositions derived from the multi-level governance framework. Then, I probe their empirical validity using evidence from developing bank regulation and supervision in Bulgaria and Hungary. According to the first proposition, experts play an essential role in policy formulation. The second proposition stipulates that public, private and international actors participate in decisionmaking and shape policy outcomes. The third proposition states that independent regulatory agencies, rather than government ministries, implement regulations and monitor compliance. The last section summarizes the findings of this article.

\section{Formulating Bank Regulations}

Proposition 1: Experts play an essential role in policy formulation.

Experts have become important participants in policy-making because of their knowledge and grasp of complex technical issues (Levi-Faur 2005). Mark Thatcher $(2002 \mathrm{~b}, 966)$ has pointed out that policy-making used to be 'the preserve of small and closed policy community, dominated by civil servants and powerful incumbent interests, especially suppliers'. By contrast, understanding the accumulation and transmission of knowledge across expert networks has become crucial in order to grasp contemporary policymaking in Europe (Kohler-Koch and Eising 1999; Knodt 2004; Kohler-Koch and Rittberger 2006). As Hooghe and Marks (2001) have shown, EU policymaking has become less hierarchical and increasingly relies on dynamic networks which involve public authorities as well as private actors and sector-specific stakeholders. 
What is the role of experts in developing banking regulations in the EU? Franco Bruni $(2008,9)$ has established that technical competence is essential in drafting European banking regulations and the participation of private interests is extensive. Lucia Quaglia (2007a) has analyzed in depth the use of comitology in the so-called 'Lamfalussy committees' ${ }^{3}$ Comitology was originally developed in order to provide member states with a control mechanism to oversee the activities of the European Commission. However, over time, it has become instrumental in providing subnational authorities and private actors with access to policy-making on the European level (Marks et al. 1996, 368). The multi-level nature of banking sector governance in the EU and the crucial role of experts are reflected in the structure of Lamfalussy committees. Level 2 Lamfalussy committees such as the European Banking Committee (EBC) have comitology functions and some advisory functions (Quaglia 2007a, 5). They are predominantly 'fora for policy debate and opinion forming' that deal with broad policy issues rather than technical details (Quaglia 2007a, 5). For example, the EBC drafts provisional proposals that take into consideration exclusively member states' preferences. By contrast, level 3 committees such as the Committee of European Bank Supervisors (CEBS) consist of representatives of member state supervisory institutions. According to Quaglia (2007a, 10), CEBS contributes extensively to the drafting and implementation of the actual standards and guidelines in banking. CEBS also conducts consultations with a considerably wider range of actors such as market participants and consumer groups and is very active in the policy implementation stage (Quaglia 2007a,13).

We thus observe evidence for an ongoing governance shift. The quest for greater expert input in the policy formulation stage was an important reason for setting up the Lamfalussy comitology structure in European bank regulation. Experts are prominent in all three levels, even though the proficiency of level 3 committees is especially detailed and relevant for the member states' national contexts. As European Central Bank (ECB) reports highlight, there has been a firm commitment to enhanced regulatory cooperation among European bank supervisors through the Lamfalussy framework that will be reinforced further by the de Larosière process (ECB 2007; European Commission 2009).

\section{Decision-making in European Bank Regulation}

Proposition 2: Public, private and international actors participate in decision-making and shape the regulatory outcomes.

Multi-level governance provides important insights about the changing role of the state in European banking sector regulation. Guy Peters and Jon Pierre $(2004,76)$ have pointed out that 'multi-level governance should not be seen as an alternative but rather as a complement to intergovernmental relations'. National banking sector regulators, usually a supervision department in the central bank or a separate supervisory agency, continue to be very important 
actors in the regulatory process because they are located closest to the regulatees and carry out all routine supervisory tasks. Yet this section presents evidence that while public authorities play an important role, international and private actors have become active and salient participants in decision-making. Bank regulations developed by the Basel Committee on Banking Supervision (BCBS) and the EU are implemented strictly on the national level. First, let us examine the influence of the BCBS. Then I will discuss the role of private actors and that of the EU.

The Basel Committee on Banking Supervision is the main international forum for cooperation on issues of bank supervision. It was established in 1974 by the central bank governors of the so-called 'Group of Ten'4 following serious disturbances in international currency and banking markets. The Committee is hosted by the Bank for International Settlements (BIS) and aims to 'improve the quality of banking supervision worldwide by exchanging information on national supervisory issues, approaches and techniques, with a view to promoting common understanding' (BIS 2007). The BCBS is not based on a founding treaty and does not issue binding regulations. According to Dieter Kerwer $(2005,619)$, the committee's main functions are 'to act as an informal forum to find policy solutions and to promulgate standards'. In 1988, the committee introduced a capital measurement system, commonly known as the Basel Capital Accord or Basel I, which stipulated a minimum capital adequacy standard of 8 per cent and provided a common approach to credit risk measurement. This framework has been widely implemented by virtually all countries with internationally active banks (BIS 2007, 2). In 1999, the committee issued a proposal for a revised Capital Adequacy Framework, known as Basel II, that was adopted in 2004 after extensive consultations with banks, industry groups, and national supervisory authorities (BIS 2007, 3). Yet, as noted earlier, the Basel Committee has no legal authority to impose its codes and standards (BIS 2007, 1). In the EU, Basel II has been incorporated in the EU's Capital Requirements Directive (CRD) adopted in 2006 and is legally binding for all EU member states.

At present, the Basel Committee on Banking Supervision is at the core of a dense international network of banking sector experts and professionals. Susanne Lütz $(2000,7)$ has examined the changing role of the committee from a forum for multilateral negotiations in the 1970s and 1980s to what she calls 'a repository of best practices' that shapes policy-makers' and practitioners' approach to bank supervision. In March 1998, the BCBS founded the 'Institute for Financial Stability' which trains national supervision personnel. The committee also participates in the 'Forum of Financial Stability' that brings together public supervisory authorities and international financial organizations such as the IMF, World Bank, BIS, OECD, and the International Organization of Securities Commissions (IOSCO).

How influential have private actors been in European banking sector governance? There is substantial evidence that large international banks have increasingly lobbied policy-makers directly on the international level (Eising 2005 , 28). For example, private actors successfully lobbied the BCBS to include a flexible supervision approach in Basel II that allows banks to use 
their own models for risk assessment in order to determine capital adequacy (Larsen 2006; Claessens et al. 2007). Organizations such as the European Banking Federation, the European Savings Bank Group, and the European Financial Services Round Table actively advocate the positions of European private banks in EU decision-making.

What EU legislation provides the framework for banking sector regulation? Initially, the Capital Adequacy Directive (93/6/EEC) and the Consolidated Banking Directive (2000/12/EC) stipulated capital requirements for banks and investment firms in EU member states. Since 2006, the key banking sector legislation has been the Capital Requirements Directive, which consists of Directive 2006/48/EC relating to the taking up and pursuit of the business of credit institutions and Directive 2006/49/EC on the capital adequacy of investment firms and credit institutions. Two additional pieces of relevant legislation are Directive 2000/46/EC regarding the taking up, pursuit of and prudential supervision of the business of electronic money institutions and Directive 2002/87/EC on the supplementary supervision of credit institutions, insurance undertakings and investment firms in a financial conglomerate.

The Financial Services Action Plan (FSAP) proposed by the European Commission in 1999 set out the first overarching EU policy in the realm of financial markets and services for the period 1999-2005. However, due to the slow implementation of the FSAP, in 2000, the ECOFIN Council appointed a Committee of Wise Men chaired by Alexandre Lamfalussy. The committee had a mandate to develop measures that would lead to convergence in regulating securities markets in the EU. In 2000, it presented a four-level approach shown here in Appendix I. The so-called 'Lamfalussy framework' was adopted in 2002 after lengthy negotiations between the European Commission and the European Parliament. In fact, the principles outlined in the Lamfalussy report for the securities sector were extended to banking and insurance (Quaglia 2007b, 278). In 2004, the European Commission reviewed the Lamfalussy process and engaged in extensive consultations in order to fine-tune its implementation. The Commission's White Paper on Financial Services 2005-2010 succeeded the FSAP (European Commission 2005b). In the aftermath of the global financial crisis, the Commission launched an initiative to redesign the European financial architecture following the recommendations of the de Larosière report. The initiative envisages the creation of a new European Systemic Risk Council (ESRC) and a European System of Financial Supervisors (ESFS), composed of new European Supervisory Authorities (European Commission 2009).

According to Lucia Quaglia (2007b, 279), the European Commission and the Committee of Wise Men clearly acted as policy entrepreneurs in developing EU financial services legislation. Quaglia (2007b, 280) points out that 'the Committee of Wise Men deliberately and strategically elicited the input of a vast array of nongovernmental actors, including first and foremost financial companies and independent experts'. Commission officials and policy-makers drafting the Lamfalussy report intentionally sought input 
from financial market operators, which is evidence for the presence of lobbying paths for international banks directly in Brussels.

As noted in the beginning of this section, the national level is still very important in governing the banking sector. Quaglia $(2007 \mathrm{~b}, 282)$ insightfully stresses that while the role of supranational and private actors has increased substantially in agenda-setting, the final decision-making stage is characterized by the strong influence of national governments in meetings of the Economic and Financial Affairs Council of Ministers (ECOFIN) and the European Council. Yet the content of European banking regulations is strongly influenced by international actors such as the BCBS and private stakeholders. Overall, we have observed that banking sector regulations are shaped by public, private, and international actors rather than exclusively national bodies.

\section{Implementing Bank Regulations}

Proposition 3: Independent regulatory agencies, rather than government ministries, implement regulations and monitor compliance.

We have seen so far that experts have gained a prominent role in formulating banking regulations. Furthermore, public, private and supranational actors all participate in decision-making and shape the regulatory outcomes. This section examines the role of independent regulatory agencies in monitoring policy implementation and ensuring compliance. Because of their proximity to the regulatees, national supervisory organizations are important actors in the banking regulatory process. With respect to institutional setup, bank regulators in Europe are either supervision departments in the central bank, as is the case in Spain and Bulgaria, or separate financial sector regulatory authorities, such as the Financial Services Authority (FSA) in the UK and the Financial Supervisory Authority (PSZÁF) in Hungary. Those organizations carry out on-site bank examinations, monitor compliance with banking sector regulations, and initiate sanctions against banks that have violated the rules.

Yet we need to analyze the role of national banking regulators in the context of the deep transformations of European economies. Since the 1970s, European states have become less involved in direct ownership and steering of the market. Instead, they have engaged extensively in 'the correction of market failures via rule-making' (Thatcher 2002a, 860). This change has led to the rise of independent regulatory agencies (IRAs). Following Mark Thatcher's (2002b, 956) definition, 'an IRA is a body with its own powers and responsibilities given under public law, which is organizationally separated from ministries and is neither directly elected nor managed by elected officials'. According to Giandomenico Majone (1994,: 89), the high level of technical expertise concentrated in IRAs and their ability to support very specialized policy-making provide an important rationale for setting up such agencies in different policy areas.

Banking sector regulators in Europe can indeed be classified as IRAs. We need to note that IRAs are not part of government ministries and their 
decisions are more consequential than those of purely consultative agencies and committees. It is beyond the scope of this article to discuss the range of national financial regulatory systems in which independent banking sector regulators are embedded. ${ }^{5}$ However, it is worthwhile mentioning that there is no identifiable trend toward adopting one particular supervision institutional setup across the EU. Member states' institutional choices have been influenced strongly by the historical evolution and relative strength of the domestic financial sector as well as national political specificities (ECB 2005, $12 ; 2008,2)$. Overall, the rise of independent banking regulators on the domestic level has boosted cooperation among experts from the public and private sectors and professionals working in different countries (Thatcher 2002a, 860; Coen and Thatcher 2005, 337).

\section{Empirical Test: The Evolution of Bank Regulation and Supervision in Hungary and Bulgaria}

Why are Bulgaria and Hungary, two new EU member states, compelling cases to investigate the dynamics of banking regulation in the Union? New EU member states had to adopt all EU-level financial regulations as part of the pre-accession process. At the same time, following the collapse of communism in 1989, Eastern European countries sought to transform their economies and extensively imported best practices from Western industrialized states. Thus new EU member states offer important evidence about policy influences from the EU level due to the accession process as well as the international level due to economic globalization.

Bulgaria and Hungary are also representative of the two most common types of banking supervision organizational structure in the EU. In Bulgaria, a supervision department within the central bank is in charge of monitoring banks and initiating sanctions. In Hungary, an independent agency, the PSZÁF, oversees the entire financial sector. Moreover, among new EU member states, Bulgaria and Hungary represent late and early reformers, respectively. Bulgaria experienced a prolonged period of partial reforms and economic stagnation until the late 1990s. In Hungary, market economy transformations took place fairly quickly in the early 1990s (Dobrinsky 2000; Vachudova 2005). Considering evidence from the two cases, let us evaluate the three propositions regarding the governance of the banking sector in the EU presented earlier.

Proposition 1: Experts play an essential role in policy formulation.

What has been the role of domestic and international experts in formulating banking regulations in Bulgaria and Hungary since 1989? Following the collapse of the communist regime in 1989, the Bulgarian National Bank (BNB) became the country's central bank. Experts from the bank, including the supervision department, took part in short-term training programmes abroad and interacted with their international counterparts (Roussenova, personal interview, 2007). However, as one interviewee pointed out, 
'political pressure on the BNB was very strong at the time' and that restricted the subsequent implementation of the international regulations and practices to which the national experts had been introduced (Ignatiev, personal interview, 2008).

Following a severe financial crisis in 1996/97 and early elections, a new centre-right government in Bulgaria embarked on a course of comprehensive economic reforms (Dobrinsky 2000; Vachudova 2005). This government welcomed foreign advisors and respected the independence of the BNB. In the area of banking supervision, my interviewees from the BNB's supervision department singled out USAID as the international organization with the most significant and lasting impact on the development of supervision rules and practices in Bulgaria (Roussenova, personal interview, 2007; Petrova, personal interview, 2008). In the aftermath of the 1996/97 crisis, about ten USAID experts worked closely with Bulgarian supervisors on a wide range of issues in the period 1998-2003. They helped draft the new Bulgarian Banking Law and develop supervision handbooks. They also accompanied Bulgarian supervisors on their on-site examinations and assisted with data collection and analysis (Ignatiev, personal interview, 2008). As one interviewee has summed up, 'the USAID experts provided very useful and relevant advice, they monitored and gave us feedback on how we implemented the new supervision guidelines' (Anonymous interview, 2008). Here we have to note the importance of Bulgarian supervisors' active interest and willingness to learn more about international rules and practices. According to senior supervisor Tatyana Petrova (personal interview, 2008), the leadership of the BNB and the Supervision Department recognized the potential benefits of USAID expertise and sought to cooperate with the US agency. Petrova also stressed that Bulgarian experts took an active role in evaluating and selecting the best practices that were most relevant for the domestic conditions.

The presence of USAID experts over an extended period of time contributed to a process of updating supervision rules in Bulgaria through dialogue and social interaction rather than mechanical rule transfer. Bulgarian supervision professionals took the initiative to 'write up, improve, and specify a lot of internal rules and principles regarding licensing, on-site examinations, and sanctions' (Timnev, personal interview, 2008). Thus when EU experts visited Bank Supervision in order to evaluate Bulgaria's readiness to apply the acquis communautaire in financial services, they found very few issues that still needed to be resolved. EU financial sector experts spent relatively little time in the organization and had a minimal impact on the way bank supervision is practised in Bulgaria (Ignatiev, personal interview, 2008).

For their part, Hungarian banking sector experts enjoyed a very permissive environment in the early 1990s with respect to the content of the new banking sector laws, including supervision rules. According to long-term supervision professional Klára Csoór (personal interview, 2006), experts had a carte-blanche to put in place the policies that they deemed necessary. Private actors also played a role in the development of bank supervision in Hungary. In the early 1990s, the Hungarian supervisory organization had limited personnel for on-site bank examinations. On several occasions, Bank 
Supervision contracted major international audit companies to carry out the on-site examinations on behalf of the organization in order to conduct the risk analysis of the banks' portfolios (Piroska 2004, 18).

Hungary actively participated in economic reform programmes organized by international actors such as the IMF and the World Bank in the early 1990s. The World Bank in particular ran a project to assist Hungarian legislators with drafting the new banking laws and advocated establishing an independent banking supervision agency (Piroska 2004, 10). Even though the World Bank organized training seminars for Hungarian bank supervisors, in the end it was a strategic domestic decision to establish and develop independent bank supervision, recruit and train professional supervisors (Csoór, personal interview, 2006). USAID experts helped prepare the guidelines for on-site bank examinations in Hungary, but they had a more limited role than in Bulgaria (Piroska 2004, 16). According to long-term supervision professional Katalin Méro (personal interview, 2006), the overall stabilization of the Hungarian banking system and introduction of prudential supervision practices took place by the end of the bank privatization in 1997, well before the beginning of accession negotiations with the EU. The start of the Lamfalussy process in the EU increased transparency and led to better coordination of supervision practices among member states (Méro, personal interview, 2006). Méro emphasized that it was not joining the EU that caused the adoption of international bank supervision standards in Hungary. In her own words, 'we did that earlier because most Hungarian private banks prefer to operate according to common international rules' (Méro, personal interview, 2006). In sum, the analysis has shown that international experts from USAID provided important assistance to Bulgarian supervision professionals in the period 1998-2003. World Bank and, to a lesser extent, USAID experts conducted training for Hungarian bank supervisors in the early and mid-1990s.

Proposition 2: Public, private and international actors participate in decision-making and shape the regulatory outcomes.

Is there evidence that national banking regulators in Bulgaria and Hungary use international supervision rules and interact with private actors? The Basel Accords developed by the BCBS for advanced industrialized countries, and taken up by many emerging economies, have been adopted in Bulgaria and Hungary as well. Yet despite the existence of legal provisions to implement the Basel I capital adequacy ratio of 8 per cent, the governments of both countries lacked political will to enforce compliance in the early 1990s (Piroska 2004, 13; Ignatiev, personal interview, 2008). In both countries, the banking sector supervisory organizations did not have sufficient operational independence from the government to pursue rule enforcement singlehandedly (Piroska 2004, 13; Ignatiev, personal interview, 2008). The implementation of Basel I and, subsequently, Basel II was stricter and more successful following the completion of bank privatization in Hungary by 1997 and the economic reforms in Bulgaria after the 1996/97 crisis. 
Both Bulgaria and Hungary had to harmonize their national legislation, including in the banking sector, with that of the EU before they could become members of the Union. Hungary applied for EU membership in 1994 and started accession negotiations in 1998, while Bulgaria applied for EU membership in 1995 and started accession negotiations in 2000. From the 31 accession negotiation chapters, ${ }^{6}$ Chapters 3 (Freedom to Provide Services) and 11 (Economic and Monetary Union) are the most relevant for banking. Let us now review Bulgaria and Hungary's progress in adopting and implementing EU banking regulations. Harmonizing the banking sector acquis was much faster and less problematic than other policy areas such as minority rights and the rule of law. Largely due to the regulatory reforms undertaken in the wake of the mid-1990s banking crises, both Bulgaria and Hungary had put in place legal and institutional structures modelled after 'best practices' in advanced industrialized economies well before the start of EU accession negotiations.

Bulgaria provisionally closed Chapter 3 very quickly compared to other policy areas: It took less than a year to harmonize the country's legislation and practices with those of the EU (European Commission 2008a). As summarized in the Commission's monitoring report, by the time of accession in 2007, the Basel II capital requirements were fully incorporated in national legislation. Furthermore, 'banking supervision is well equipped and competently supervises the banks ... the capacity and expertise of the supervision has been constantly upgraded' (European Commission 2005a, 31). It took only a month to harmonize Chapter 11 legislation (European Commission 2008b).

Hungary opened Chapter 3 in 1999 and closed it provisionally in 2000 (European Commission 2008a). Similar to the dynamics in Bulgaria, Chapter 11 was closed faster, for several months in 1999 (European Commission 2008b). According to the European Commission's assessment, 'the Hungarian Financial Supervisory Authority essentially has the required infrastructure and human resources to deal with the acquis-related tasks in the field of financial institutions' (European Commission 2003, 22). With respect to Chapter 11, the Commission concluded that 'Hungary has met the commitments and requirements arising from the accession negotiations and is in a position to implement the acquis' (European Commission 2003, 33).

To what extent do private actors influence bank regulations in Bulgaria? Supervision professionals maintain contacts with the commercial banks on several organizational levels: experts, directors, and even BNB governors if there is a serious issue that needs to be resolved (Timnev, personal interview, 2008). Supervisors aim for active cooperation with their counterparts in the commercial banks and strive for 'very professional and respectful relations' (Petrova, personal interview, 2008). Professionals working at the commercial banks are frequently in contact with the Bank Supervision Policy and Methodology Department, headed by Tatyana Petrova, to receive methodological recommendations and practical advice. Those contacts are problem-driven rather than codified (Petrova, personal interview, 2008). 
Bank Supervision's Legal Department regularly consults with the Association of Banks in Bulgaria, the main peak association in the sector, regarding any forthcoming regulatory changes. The Association receives drafts of planned regulatory changes, submits written positions on the drafts, and often puts forward proposals for regulatory changes in line with the needs and preferences of its members (Ivanova, personal interview, 2009). In turn, supervision experts usually take into account the Association's feedback, as long as it 'does not contradict the established goals and principles of the organization' (Timnev 2008, personal interview). Supervisors also maintain contacts with commercial banks' private auditors in order to check how a different organization assesses banks' risks and verify the reliability of banks' self-reported information (Petrova, personal interview, 2008).

Similarly, the main peak association in Hungary, the Hungarian Banking Association (HBA), participates in the drafting and discussion of laws affecting the banking sector. The association presents and advocates policy proposals based on consensus among its 44 members. It also reviews the regulatory proposals of the Hungarian National Bank and closely cooperates with the Hungarian Financial Supervisory Authority (HBA 2009). As the Association's annual reports demonstrate, its comments and proposals regarding banking sector regulations are taken seriously and frequently incorporated in forthcoming legislation (HBA 2001-2008). A member of the European Banking Federation, the HBA also pushes for the application of international banking standards domestically and training activities for professionals working in the commercial banks. Thus we have found support that national banking sector regulators in Bulgaria and Hungary have endorsed international standards such as the Basel Accords, effectively adopted all relevant EU banking sector legislation, and regularly consult private actors.

Proposition 3: Independent regulatory agencies, rather than government ministries, implement regulations and monitor compliance.

In Bulgaria, Bank Supervision is a department within the central bank the BNB. As the BNB was not fully independent of political pressure before the 1996/97 economic crisis, the supervision department could not conduct its activities independently either. In the aftermath of the crisis, the new government introduced a currency board and guaranteed central bank independence. The new Bulgarian Banking Law and the Law on the BNB, both adopted in 1997, contained stricter and more precise supervision requirements as well as more severe penalties (Ignatiev and Simeonov 1999). Over time, Bank Supervision gained more independence from political interference and also more organizational responsibilities especially in the realm of granting bank licences and imposing sanctions (Ignatiev and Simeonov 1999). The Bulgarian government established a separate Financial Supervision Commission in March 2003 that is responsible for the integrated supervision of securities, exchanges, insurance, and pension funds. According to senior supervision professional Tatyana Petrova (personal interview, 
2008), Bank Supervision is appropriately situated within the BNB, because since the beginning of transition the Bulgarian banking sector has been more developed and complex than securities and insurance.

Since the 1996/97 crisis, Bulgarian supervisors have taken a more proactive stance in enforcing bank regulations. Several bank licences were revoked due to solvency concerns (Ignatiev and Simeonov 1999). Cornerstone reforms in the banking sector and supervision took place by the end of bank privatization. When EU accession negotiations began in 2000, in the words of one supervision professional, 'We were able to close the financial services chapters very quickly because after the 1996/97 crisis, we introduced better standards and more discipline in the sector' (Timnev, personal interview, 2008). Even when EU bank regulations allow more discretion in national implementation, Bulgaria's Bank Supervision tends to adopt a more conservative stance to ensure the stability of the financial system and avoid crisis (Anonymous interview, 2008).

With respect to the influence of government ministries and political parties, a long-term supervision professional in Bulgaria stressed that political interference either from the governing or other political parties is now unacceptable (Anonymous interview, 2008). Unlike in Hungary, since the beginning of transition, Bulgaria's Bank Supervision has not been influenced significantly by the Ministry of Finance (Avramov, personal interview, 2009; Ganev, personal interview, 2009).

The Hungarian Financial Supervisory Authority (PSZÁF) that currently oversees banking, securities, insurance, and pension funds was established in April 2000. Before the creation of the single financial supervisory organization, Hungary had a joint banking and capital market supervision agency since 1996, and a separate entity for overseeing securities, exchange, and pension funds (Piroska 2004). In her comprehensive analysis of the development of bank supervision in Hungary and Slovenia, Dóra Piroska (2004) has argued that since the 1990s international actors have advocated shielding Hungary's bank supervision from political interference. In Piroska's (2004, 8) view, there has been a strong consensus among international experts in favour of independent banking supervision that mirrors the broad international consensus in support of central bank independence (Maxfield 1998; Marcussen 2005; Epstein 2006; Johnson 2006).

The Hungarian case offers important insights into the tension between government ministries and independent regulatory agencies. Before the PSZÁF asserted itself as the main public regulator in the financial sector, the Hungarian Finance Ministry and the Hungarian National Bank also sought to influence bank regulations. According to Piroska (2004, 23), in the early 1990s the Finance Ministry 'often behaved as if the supervision agency was part of its own greater bureaucratic organization'. In fact, the very origins of bank supervision in Hungary go back to the country's Finance Ministry. In the late 1980s, '6 people at the Finance Ministry supervised the entire banking sector' (Pirsoka 2004, 21). The HNB has been interested in managing the macroeconomic parameters in the sector according to its priorities, but has been willing to leave micromanagement issues to Bank Supervision (Csoór, 
personal interview, 2006). For its part, the Finance Ministry sought to influence decisions regarding bank taxation in order to maximize tax revenues. Yet the two big public institutions, the HNB and the Ministry of Finance, could not agree on the precise role of Bank Supervision which, in the long run, boosted the organization's independent credentials. Successive Heads of Supervision pursued greater independence and legitimacy of the organization. In the words of former Head of Supervision Tamás Rusznák, cited in Piroska $(2004,23)$, 'I wanted the agency not to be supervised by the Ministry of Finance or the government ... as in the operation of those two institutions the conflicting goals of fiscal policy and bank supervision become immediately evident'.

Overall, we have seen that in both Bulgaria and Hungary independent regulatory agencies monitor and ensure compliance with bank supervision rules. Bulgaria's Bank Supervision Department, organizationally situated within the central bank, has enjoyed significant independence from political pressure since the 1996/97 economic crisis and subsequent economic reforms. Hungary's Bank Supervision, situated within the financial sector regulator PSZÁF, faced challenges from the Finance Ministry but has asserted itself as the main public regulator in banking.

\section{Conclusion}

This article has demonstrated that the insights of multi-level governance apply beyond the regional development and structural policies of the EU. The value-added of the MLG framework is that it can systematically account for the governance shifts in European banking regulation observed since the 1990s. The article examined changes that have occurred in three important stages of the policy cycle - policy formulation, decision-making, implementation - and probed empirically three propositions derived from the MLG framework.

According to the first proposition, experts play an essential role in policy formulation. Indeed, the empirical analysis has shown that international experts from USAID provided important assistance to Bulgarian supervision professionals in the period 1998-2003. World Bank and, to a lesser extent, USAID experts coached and consulted Hungarian bank supervisors in the early and mid-1990s. The second proposition states that public, private, and international actors participate in decision-making and shape the regulatory outcomes together with national regulators. We have found evidence that national bank regulators in both Bulgaria and Hungary have endorsed international standards such as the Basel Accords and have effectively adopted all relevant EU banking sector legislation. Private actors, especially the national peak associations of commercial banks, have actively influenced this process. According to the third proposition, independent regulatory agencies, rather than government ministries, implement regulations and monitor compliance. In support of this proposition, we saw that Bulgaria's Bank Supervision, organizationally situated within the central bank, has enjoyed significant independence from political pressure since the 1996/97 economic crisis and 
subsequent economic reforms. Hungary's Bank Supervision, situated within the overarching financial sector regulator PSZÁF, faced challenges from the Finance Ministry but has asserted itself as the main public regulator in banking.

\section{Acknowledgement}

I would like to thank the interviewed banking supervision professionals and academics for their time and sharing valuable insights into the regulatory process. I am grateful to the participants in the ECPR Joint Sessions 2009 Workshop 9 and three anonymous JEI referees for their constructive comments on earlier versions of the paper.

\section{Notes}

1. This article treats international banking regulation as a subset of policies within the broader framework of international financial regulation which also encompasses insurance and securities.

2. It is beyond the scope of the article to discuss the debate between the rationalist and the constructivist schools. Two excellent pieces that provide an overview of what is at stake in this debate are Finnemore and Sikkink's (2001) article on constructivism in international relations and comparative politics and Jupille et al.'s (2003) survey article on integrating rationalism and constructivism in the study of the European Union. As an example of convincing synthesis of rationalism and constructivism, Thomas Conzelmann $(1998,9)$ has employed effectively both rationalist and constructivist arguments in his multi-level governance analysis of Germany's regional policy.

3. Appendix I provides a diagram of the Lamfalussy process. At the time of writing, the European Commission announced further streamlining of the European financial regulatory framework following the recommendations of the de Larosière report (see European Commission 2009).

4. The 'Group of Ten' is comprised of eleven industrialized states that consult and cooperate on economic, monetary, and financial matters. Those states are Belgium, Canada, France, Germany, Italy, Japan, the Netherlands, Sweden, Switzerland, the United Kingdom, and the United States. Luxembourg and Spain are also members of the Basel Committee.

5. Kremers et al. (2003) present a lucid and comprehensive analysis of the pros and cons of a single supervision entity for the entire financial sector versus multiple supervision organizations focusing on specific fields such as banking, insurance, and securities.

6. Since 1998, the European Commission has published annual reports on the progress of each candidate country toward membership in the EU. The acquis communautaire is organized in 31 negotiation chapters, based on which the Commission specifies pieces of legislation that need to be adopted or amended to achieve full compliance.

\section{References}

Bank for International Settlements. 2007. History of the Basel Committee and its membership, http:// www.bis.org/bcbs/history.pdf.

Barth, J., G. Caprio, and R. Levine. 2006. Rethinking bank supervision: till angels govern. Cambridge: Cambridge University Press.

Bruni, F. 2008. The governance of EU's financial regulation: challenges from the current financial turmoil. Presentation, Chatham House, 25 January.

Caporaso, J. 1996. The European Union and forms of state: Westphalian, regulatory or post-modern. Journal of Common Market Studies 34, no. 1: 29-52.

Cerny, P. 2005. Power, markets and accountability: the development of multi-level governance in international finance. In Governing financial globalization: international political economy and multi-level governance, ed. A. Baker, D. Hudson and R. Woods, 24-48. London: Routledge. 
Claessens, S., G. Underhill, and X. Zhang. 2007. The political economy of Basle II: the costs for poor countries. World Economy and Finance Programme Working Paper, http://papers.ssrn.com/sol3/ papers.cfm?abstract_id=944530\&high=\%20claessens.

Coen, D., and M. Thatcher. 2005. The new governance of markets and non-majoritarian regulators. Governance: An International Journal of Policy, Administration, and Institutions 18, no. 3: 329-46.

Conzelmann, T. 1998. Europeanisation of regional development policies? Linking the multi-level governance approach with theories of policy learning and policy change. European Integration Online Papers-EIoP 2, no. 4: 1-23.

Dobrinsky, R. 2000. The transition crisis in Bulgaria. Cambridge Journal of Economics 24: 581-602.

Eising, R. 2005. The access of business interest to European Union institutions: notes towards a theory. Working Paper No. 29, ARENA Centre for European Studies, University of Oslo.

Epstein, R.A. 2006. Cultivating consensus and creating conflict. international institutions and the (de)politicization of economic policy in postcommunist Europe. Comparative Political Studies 39, no. 8: 1019-42.

European Central Bank. 2005. Banking structures in the new EU member states. Frankfurt: ECB.

European Central Bank. 2007. Review of the Lamfalussy framework. Eurosystem Contribution. Frankfurt: ECB.

European Central Bank. 2008. EU banking structures. Frankfurt: ECB.

European Commission. 2003. Comprehensive monitoring report on Hungary's preparations for membership, http://ec.europa.eu/enlargement/archives/key_documents/reports_2003_en.htm.

European Commission. 2005a. Bulgaria: 2005 comprehensive monitoring report, http://ec.europa.eu/ enlargement/archives/pdf/key_documents/2005/sec1352_cmr_master_bg _college_en.pdf.

European Commission. 2005b. White paper. Financial services policy 2005-2010, http://ec.europa.eu/ internal_market/finances/policy/index_en.htm\#20051205.

European Commission. 2008a. Enlargement archives. Enlargement process. Negotiations of Chapter 3, http://ec.europa.eu/enlargement/archives/enlargement_process.

European Commission. 2008b. Enlargement archives. Enlargement process. Negotiations of Chapter 11, http://ec.europa.eu/enlargement/archives/enlargement_process.

European Commission. 2009. European financial supervision. COM(2009) 252 final.

Finnemore, M., and K. Sikkink. 2001. Taking stock: the constructivist research program in international relations and comparative politics. Annual Review of Political Science 4: 391-416.

Genschel, P., and T. Plümper. 1997. Regulatory competition and international co-operation. Journal of European Public Policy 4, no. 4: 626-42.

Helleiner, E. 1994. States and the reemergence of global finance. From Bretton Woods to the 1990s. Ithaca,NY: Cornell University Press.

Hooghe, L., and G. Marks. 2001. Multi-level governance and European integration. New York: Rowman and Littlefield.

Hooghe, L., and G. Marks. 2003. Unraveling the central state, but how? Types of multi-level governance. American Political Science Review 97, no. 2: 233-43.

Hooghe, L., and G. Marks. 2004. Contrasting visions of multi-level governance. In Multi-level governance, ed. I. Bache and M. Flinders, 15-30. Oxford: Oxford University Press.

Howlett, M., M. Ramesh, and A. Perl. 2009. Studying public policy. policy cycles and policy subsystems. Oxford: Oxford University Press.

Hungarian Banking Association. 2001-2008. Annual report on activities, http://www.bankszovetseg.hu/ bankszovetseg.cgi.

Hungarian Banking Association. 2009. Introduction, http://www.bankszovetseg.hu/bankszovetseg.cgi.

Ignatiev, P., and R. Simeonov. 1999. Structure and conduct of bank supervision in Bulgaria. In Banking sector management under currency board. Sofia: Institute for Market Economics.

Johnson, J. 2006. Postcommunist central banks: a democratic deficit. Journal of Democracy 17, no. 1: 90-103.

Jupille, J., J. Caporaso, and J. Checkel. 2003. Integrating institutions: rationalism, constructivism, and the study of the European Union. Comparative Political Studies 36, no. 1/2: 7-40.

Kapstein, E.B. 1989. Resolving the regulator's dilemma: international coordination of banking regulation. International Organization 43, no. 2: 323-47.

Kapstein, E.B. 1994. Governing the global economy: international finance and the state. Cambridge, MA: Harvard University Press. 


\section{Aneta B. Spendzharova}

Keohane, R., and J. Nye. 2000. Introduction. In Governance in a globalizing world, ed. J. Nye and J. Donahue, 1-44. Washington, DC: The Brookings Institution.

Kerwer, D. 2005. Rules that many use: standards and global regulation. Governance 18, no. 4: 611-32.

Knodt. M. 2004. International embeddedness of European multi-level governance. Journal of European Public Policy 11, no. 4: 701-19.

Kohler-Koch, B., and R. Eising, eds. 1999. The transformation of governance in the European Union. London: Routledge.

Kohler-Koch, B., and B. Rittberger. 2006. Review Article: The 'governance turn' in EU studies. Journal of Common Market Studies 44, no. 1:27-49.

Krasner, S.D., ed. 1983. International regimes. Ithaca, NY: Cornell University Press.

Kremers, J., D. Schoenmaker, and P. Wierts. 2003. Cross-sector supervision: which model? BrookingsWharton Papers on Financial Services: 225-43.

Larsen, P.T. 2006. Basel II best for biggest in bank’s view. Financial Times, 10 April 2006.

Levi-Faur, D. 2005. 'Agents of knowledge' and the convergence on a 'new world order': a review article. Journal of European Public Policy 12, no. 5: 954-65.

Lütz, S. 2000. Beyond the Basel Accord: banking regulation in a system of multilevel governance. Paper presented at the 41st Annual Convention of the International Studies Association, Los Angeles, CA, 14-18 March.

Majone, G. 1994. The rise of the regulatory state in Europe. West European Politics 17, no. 3: 77-101.

Marcussen, M. 2005. Central banks on the move. Journal of European Public Policy 12, no. 5: 903-23.

Marks, G., L. Hooghe, and K. Blank. 1996. European integration from the 1980s: state-centric v. multilevel governance. Journal of Common Market Studies 34, no. 3: 341-78.

Maxfield, S. 1998. Gatekeepers of growth: the international political economy of central banking in developing countries. Princeton, NJ: Princeton University Press.

Perraton, J., and P. Wells. 2004. Multi-level governance and economic policy. In Multi-level governance, ed. I. Bache and M. Flanders, 179-94. Oxford: Oxford University Press.

Peters, G., and J. Pierre. 2004. Multi-level governance and democracy: a Faustian bargain? In Multi-level governance, ed. I. Bache and M. Flanders, 75-92. Oxford: Oxford University Press.

Piattoni, S. 2009. Multi-level governance: a historical and conceptual analysis. Journal of European Integration 31, no. 2: 163-80.

Piroska, D. 2004. How is the global-state formed? Internationalization of global norms by local institutions: banking sector supervision in Hungary and Slovenia. Paper presented at the 6th annual meeting of the Society for Comparative Research, University of California - San Diego, 14-15 May.

Quaglia, L. 2007a. Committee governance in the financial sector in the European Union. Sussex European Institute Working Paper No. 96.

Quaglia, L. 2007b. The politics of financial services regulation and supervision reform in the European Union. European Journal of Political Research 46: 269-90.

Rosenau, J. 1997. Along the domestic-foreign frontier. Exploring governance in a turbulent world. Cambridge: Cambridge University Press.

Ruggie, J.G. 1982. International regimes, transactions, and change: embedded liberalism in the postwar economic order. International Organization 36, no. 2: 379-415.

Ruggie, J.G. 1993. Territoriality and beyond: problematizing modernity in international relations. International Organization 46: 139-74.

Thatcher, M. 2002a. Analyzing regulatory reform in Europe. Journal of European Public Policy 9, no. 6: 859-72.

Thatcher, M. 2002b. Regulation after delegation: independent regulatory agencies in Europe. Journal of European Public Policy 9, no. 6: 954-72.

Vachudova, M.A. 2005. Europe undivided: democracy, leverage, and integration after communism. Oxford: Oxford University Press. 


\section{Appendix I}

\section{Level 1}

Commission adopts formal proposal for Directive/Regulation after a full consultation process

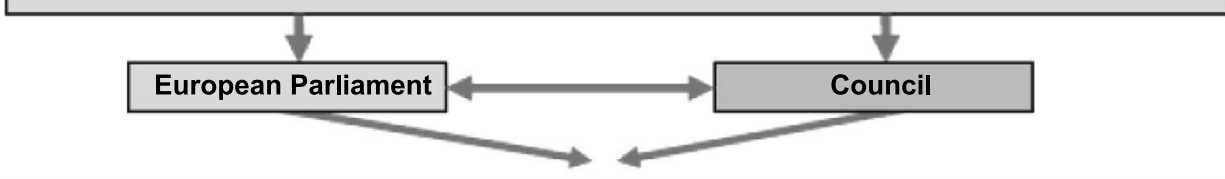

Agreement on framework principles and definition of implementing powers in Directive/Regulation (co-decision)

\section{Level 2}

Commission, having consulted Level 2 Committee (ESC, EBC, EIOPC), requests advice from Level 3 Committee (CESR, CEBS, CEIOPS) on technical implementing measures

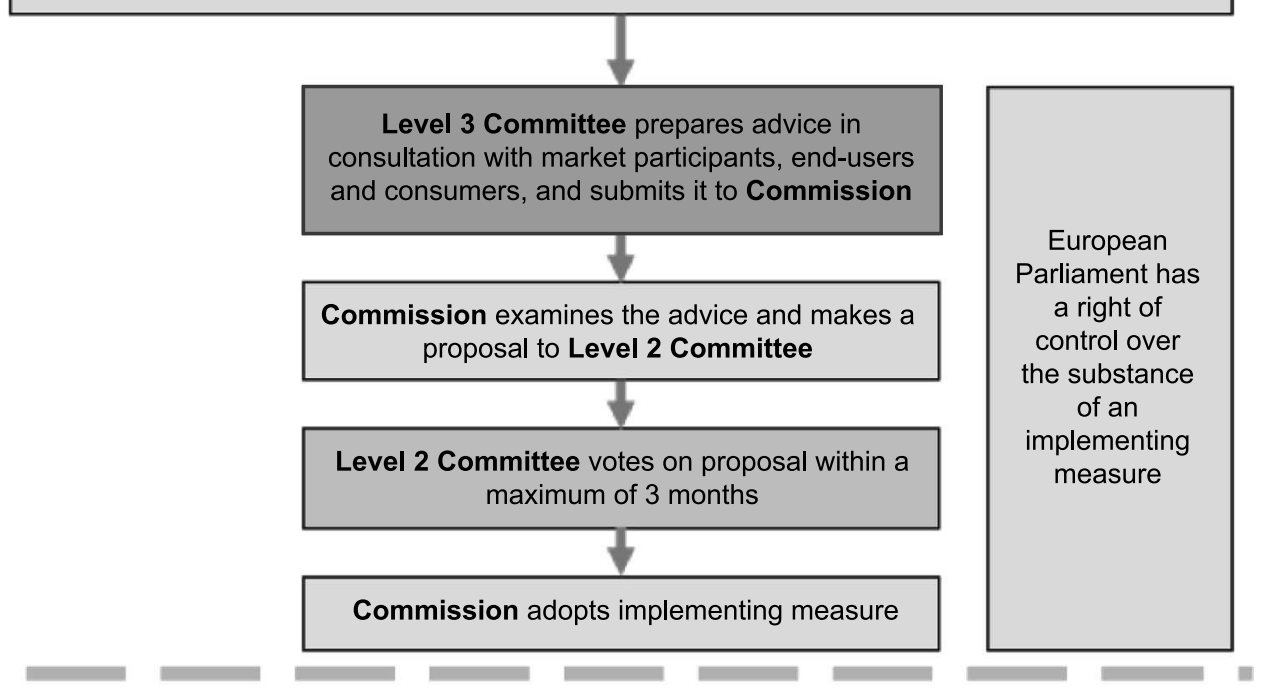

\section{Level 3}

Level 3 Committee (CESR, CEBS, CEIOPS) works on day-to-day administrative quidelines, joint interpretation recommendations and common standards (in areas not covered by EU legislation), peer review, and compares regulatory practice in Member States to ensure consistent implementation and application

\section{Level 4}

\section{Strengthened enforcement of Community Law (Commission)}

Figure A1. The four-level regulatory approach under the Lamfalussy process. Source: European Commission, 'Review of the Lamfalussy Process. Strengthening Supervisory Convergence', Brussels, COM(2007) 727 final: 14. 


\section{Appendix II. List of interviews}

\section{Bulgaria}

Anonymous interview: Bank Supervision BNB, 13 May 2008.

Avramov, Roumen: Academic and NGO Expert, Centre for Liberal Strategies (Programme Director Economic Research), 25 March 2009.

Ganev, Georgy: Academic and NGO Expert, Centre for Liberal Strategies (Programme Director Economic Research), 25 March 2009.

Ignatiev, Petar: Analyst, United Bulgarian Bank. Previously: Expert, Bank Supervision BNB, 13 May 2008.

Ivanova, Kalina: Association of Banks in Bulgaria (ABB), 26 March 2009.

Petrova, Tatyana: Director, Bank Supervision Policy and Methodology BNB, 16 May 2008.

Roussenova, Lena: Member of the BNB Governing Council 1996-1997, 22 July 2007.

Timnev, Tihomir: Expert, Bank Supervision Legal Department BNB, 15 May 2008.

\section{Hungary}

Andor, László: Academic, 18 April 2006.

Csaba, László: Academic; Previously Hungarian Finance Minister, 11 April 2006.

Csoór, Klára: Senior Counsellor in PSZÁF, 12 April 2006.

Horvath, Julius: Academic, 13 April 2006.

Méro, Katalin: Managing Director of PSZÁF, 19 April 2006.

Soós, Károly Attila: Researcher; Previously Member of the Hungarian Parliament, 10 April 2006. 